\title{
Perceiving precarity and extremism in Nuruddin Farah's North of Dawn
}

Somali citizens, both at home and abroad, have been reduced to a life of uncertainty, instability and insecurity. This article considers Somalis as part of the 'precariat' (as theorized by Pierre Bourdieu, Guy Standing, and others). Drawing on critical terrorism and trauma scholarship, the article gauges the experiences of the precariat subject, highlighting how these experiences affect the daily lives of the Somali migrant community in Nuruddin Farah's North of Dawn (2018). The aim of this article is to consider the relationship among precarity, extremism and the postcolonial émigré with regard to the contingent and fractious relations established by and between the Somali migrant characters and their hosts in the novel. Whereas predominant framings of precarity are characterized by labor insecurity, lack of any stable economic identity, and the fear of losing what one has, my argument in this article is that extremism is both a response to and attendant agent of precarity as presented in the novel. My contention is that Farah engages the precariat as extremist in the narrative present of the novel, highlighting the ways in which those that face social identification and marginalization are both at risk and risky to others. Keywords: precariat, Somali migrant community, extremism, social marginalization, African migration literature, trauma.

\section{Introduction}

The novelist, essayist, poet, playwright and social critic, Nuruddin Farah, is no stranger to many scholars. His popularity is not a result of the numerous awards he has garnered over the years-he is the recipient of several literary prizes, besides being a perennial nominee for the Nobel Prize in Literature—or skills in fiction writing, but mainly a result of his unwavering commitment to chronicling the effects on ordinary lives of his country's social and political upheavals. This article offers a reading of Nuruddin Farah's North of Dawn from the perspective of precarity and extremism. It is about how the novelistic genre explores what Hanna Arendt calls "the banality of evil" in human affairs. I will argue that, at its best, Farah writes terrorist subjectivities in the novel that openly embody violence, cruelty and intentional infliction of human suffering on others "as the only means of escape from the maddening paradoxes of their societies" (Zulaika 95). In the narrative context of North of Dawn, these "maddening paradoxes" emanate from the way the Somali postcolony is configured in scholarship on Somalia. According to Hassan Mohamed, Somalia stands out as the only African country that was partitioned into five separate parts during the colonial period: British Somaliland in the north; North Frontier District (NFD, which was later ceded to Kenya by Britain); Italian Somaliland in the south; French Somaliland (now Djibouti); and a large region known as Ogaden of which all three European powers relinquished portions to Emperor Menelik of Ethiopia as a reward for his collaboration (Mohamed 7). Out of these five, only two parts of the Somali nation-the former British Somaliland and former Italian Somaliland - gained independence and united, on 1 July 1960, to form what came to be known as the Somali Democratic Republic. In pointing out the destruction of Somalia and the fabric of the Somali nation, Mohamed suggests that the real causes of civil strife in Somalia lie less with the nature of clan segmentation and more with the impact of the partition of the Somali nation; the manipulation by the ruling elites of the Somali segmentary social system; the marginalization of the indigenous social system; and the inadequacy of the mediating role of the rulers and the state mechanisms that replaced it (Mohamed 10). This emphasis on the reasons behind internal fissures in Somalia is also echoed by Ken Menkhaus, who notes that the country has lacked a functioning government since the ousting from power of President Muhammed Siyad Barre in 1991, and, in his view, this is partly due to the legacy of Barre's regime: "The harsh repression of the government of Moham-

Nick Mdika Tembo is a senior lecturer in the English Department at the University of Malawi, Zomba, Malawi.

Email: ntembo@cc.ac.mw

(D) https://orcid.org/0000-0002-9572-9763

DOl: dx.doi.org/10.17159/2309-9070/tvl.v.57il.8079

DATES:

Submitted: 10 July 2019; Accepted: 14 August 2019; Published: 28 April 2020 
med Siad Barre fueled sharp resentment toward and fear of the state itself in the Somali public. The Barre regime's divide-and-rule tactics stoked deep interclan animosities and distrust, and are held partially responsible for the failure of clans to unite in a post-Barre government" (Menkhaus 78-80). The two writers above draw attention to the fact that Somalia and her people were thrown in a state of precarity and precariousness since "competing factions and anarchy filled the resulting vacuum" (Lyons and Samatar 7) left by Barre, which has led to violence, looting and millions of people dying while some of them flee the country every year. Nuruddin Farah appears to underscore this point in the opening paragraph of North of Dawn, noting that "no one knows how many people have been injured or how many have been killed" (l) ever since the implosion started.

Edward Said argues that terror "has spawned uses of language, rhetoric and argument that are frightening in their capacity for mobilizing opinion, gaining legitimacy and provoking various sorts of murderous action" (Said 149).Writing about terror and the postcolonial, Elleke Boehmer and Stephen Morton seem to extend Said's argument when they reckon that "terrorism has not only been constituted as an object of contemporary knowledge, but [...] it [also] defines the twenty-first-century Western zeitgeist" (Boehmer and Morton 7-8). These observations ring true in many scholarly engagements with the term. What remains surprising is that for a phenomenon that is so pervasive not only in the West but also on the African continent, terrorism is relatively understudied in African literary criticism. In most countries, much of this terror is significantly marked by a fractured relationship between the state and its citizens. Extremism, then, is enduringly described through the terror it strikes in people. For Boehmer and Morton, this terror induces affect. The two scholars presciently note how "extreme fear, galvanizing shock, vengeful anger, displacement, and [...] paranoia" (Boehmer and Morton l) are among the affective repercussions of terror. This article gauges the vicarious experience of extremism and its attendant motivations, highlighting how it affects the daily practices of the Somali migrant community in the narrative context of North of Dawn. Spatially, the article traces what happens to the people fleeing conflict and violence when the world they have known all along appears to have gone missing and they are forced to lead a precarious life in a relocated environment. It also explores what is at stake in the representation of precarity and extremism in African writing.

North of Dawn is Nuruddin Farah's latest novel. Like most of his books, it is a "commentary on Somalia and the history of Somalia" (Alden and Tremaine 43), following and reflecting the changes Somalia has undergone since independence. The novel tells the story of a Somali migrant family torn between kindness and doing the right thing. Tension is brought to its head between Gacalo and Mugdi, the migrant couple who go out of their way to shelter the wife of their radical son, now dead. Gacalo has the tenderness and love of a woman that wants her son's widow, Waliya, to come and stay with them in Norway, while Mugdi fears that Waliya's presence would only remind him of their son's involvement in terrorism. After their son had killed himself in an al-Shabaab-sponsored bomb attack in Mogadishu, Mugdi had vowed not to show sorrow for his death. In the end though, kindness wins as Mugdi reluctantly concedes to taking in their daughter-in-law. This is how Ron Charles highlights Mugdi's aversion towards Waliya through a palpable tension that also sets the tone of the novel, when the two meet at the airport:

Mugdi is thrust into the awkward role of welcoming a daughter-in-law poisoned by the same radicalism that turned his son into a killer. She arrives from a refugee camp in a state of terrified bewilderment, fully cloaked, unwilling to speak to him —or any man — directly. Even before they've left the Oslo airport, we can see the clash of secular and religious values that will confound this awkward new family. ("North of Dawn by Nuruddin Farah, Review" n. p.)

In the event of reading North of Dawn then, the reader experiences the uncomfortable situation Mugdi and Gacalo put themselves in, perhaps wondering if the two of them will not be misconstrued as terrorists by association. The narrative present is constantly interrupted by memories and fears-notably, fears from Gacalo, Mugdi and a host of other naturalized Somalis in Norway - about how they might be perceived by their hosts if they do not behave according to the expectations of the Norwegians. Needless to wonder, the novel's narrator notes that "the onus of is on Somalis to improve their chance of success wherever they happen to be" (Farah 224). These fears are encountered within the diegesis of the novel, articulated through the eyes of the novel's principal characters.

The book's title adds to the narrative ambience of the plot of the novel. Farah makes a play on the words north and dawn to suggest that something is literally out of joint on the other side of dawn. In literary studies, dawn conjures notions of illumination and hope, the beginning of a new day and thus a chance for happiness and improvement. Something on the north of dawn is, in this case, out of sync with hope or a new beginning. It is a morning that brings with it some sort of uneasiness. It is this uneasiness that sustains the novel's plot as the 
author works to articulate Somalia's social ills as a nerve center that inaugurates the irrepressible rage that his characters demonstrate in the novel. Farah reads Somalia as a place of hell because of the folly of a few misguided individuals at the top. Somalia is, as Farah presents his imaginary state through the character of Mugdi in North of Dawn, "just as frightening to the victims caught in the snares of its cruelty" today (295). Presented this way, Somalia's violent past imputes a burden of unexpressed anger on the present generation, and has been a source of pain and resentment to the Somali community both at home and abroad. Farah uses the creative medium as an ideological weapon to present an authentic and balanced view of his country without embellishing or romanticizing anything about it. In his writing, especially his long fiction, Farah has consistently taken umbrage at the Somali leadership, accusing it of not doing enough to save Somalia from degenerating into further clan-based anarchy. He underscores this point in North of Dawn, where he maintains that Somalia is ravaged from within by its clan-based leaders, leaving dire consequences in its wake. For Farah,

the implosion has not been limited to the country and those who live in it. The collapse has had repercussions for every Somali around the world, no matter if they are still in the country or if they abandoned the country to its tragic fate and sought refuge in other lands. These seismic consequences haunt even those Somalis who have never known the country, whether because they left when very young, or were born elsewhere to parents who had fled fighting. (North 294)

These "seismic consequences" have in some ways produced the kind of precarity that engages and transcends the palpable anxieties, traumas and frustrations that directly bear on the postcolonial/raced Somali émigré. Although North of Dawn is concerned with the difficult questions of forgiveness and recovery in the aftermath of violence, in this article the figuring of the ravages of terrorism will be my primary concern. I argue that Farah engages the precariat as extremist in his new novel as a way of re-envisioning Somali anxieties in exile.

Farah's singular achievement in North of Dawn is to show how the novel's characters react in the face of past frustrations that appear to follow them all the way to far-flung places. The article reflects on the question of re-placing Nuruddin Farah vis-à-vis other Somali émigrés. I use the term re-placing in the sense of discursive re-locations of Somalis from their natal homes to other 'homes' outside the political and geographical spaces of Somalia, focusing on how this class relates both with the host society and its homeland. Farah himself has been living outside his country for over forty years, having left Somalia in 1974. Over the years, his compatriots have followed suit, becoming refugees in Africa, and parts of America and Europe.

I make this argument about how Farah and his compatriots' migration is an act of re-placing Somalis in three distinct ways. First, I concur with Farah's observation that Somalia is a country in a state of flux. This population has precariously re-placed itself elsewhere, in the sense that re-placing is here understood as the act of finding a new place, a new home away from home. Second, and related to the new Somali émigré, Somali migrants are being replaced discursively by a new crop of Somalis "born in one country, brought up in another as a refugee, and now thrust into a third" (North 150). This is a new class of people that appears to have no inkling about what drove their parents out of Somali; but who, nevertheless, have to contend with their persona non grata status and they reinvent themselves and their identity in their new environments. What sort of relationship do all these Somalis have towards both their host countries and their ancestral or natal home? Finally, Somali émigrés and 'Somaliness' are being re-placed and/or re-engaged institutionally, as an academic discipline. In various disciplines, scholars are bringing the Somali phenomenon into academic discourse through journal and book length issues dedicated to its study, conferences organized around research on it, and overall consideration of the implications of its changes for how they conceptualize their disciplines. This theme issue on Nuruddin Farah is perhaps one such endeavor aimed at examining Somali studies in the academy.

The words precarity and precariat will need a brief explication. Precarity, awkwardly translated from the French word precarite, "came into wide circulation in Europe in the 1980s in response to labor reforms and the reduction of welfare state provisions" (Han 335). It refers to "the predicament of those who live at the juncture of unstable contract of labor and a loss of state provisioning" (332). Pierre Bourdieu explicates precarity in terms of the "weight of the world" that embodies "social suffering in contemporary society" through degradation of work, a fractured and racializing citizenship, and excessive human vulnerability. Nicholas Ridout and Rebecca Schneider seem to extend Bourdieu's views, describing precarity in terms of an existence without the predictability of security. For them, precarity is a "situation wherein your tenancy on your land is in someone else's hands" (n. p.). The precariat, therefore, is a social group formed by people suffering from precarity. Guy Standing defines the precariat as a class-in-the-making or a class-for-itself that is characterized by labor insecurity, lack of any stable economic 
identity, and the fear of losing what one has (The Precariat: The New Dangerous Class 63). This article does not so much focus on the anxieties surrounding (un)employment as given in the two definitions, more so since Waliya, one of the characters involved in extremism in the novel, is "not interested in seeking a job or even working" (North 105); rather, it traces the various connotations of loss, in-between-ness, marginality, feelings of abandonment, and the attendant rage brought about by the condition of precarity.

The central tenets of precarity and risk society can help enrich our understanding and analysis of conditions of civil conflict and migration and, in turn, enliven the narrative plot of North of Dawn. In the next section, I aver that Farah's latest novel focuses on the pathology of the traumatized subject. I also explore the fear, anger and seething discontent that reverberate through a community alienated from and living on the fringes of the host society. This explains why I propose that radicalism is both a response to and attendant agent of precarity in the novel. My attempt at retheorizing precarity and risk society, therefore, will take up this understanding, exploring the pestilence that has dogged the Somali postcolony which has, in turn, produced the precariat as extremist.

\section{'Risk society' trauma and haunting in North of Dawn}

In analyzing the thematic core of Farah's latest novel, it is useful to think about German sociologist Ulrich Beck's construction of the term risk society, a term that suggests fear and uncontrollability in human beings. According to Beck, the risk society "epitomizes an era of modern society that no longer merely casts off traditional ways of life but rather wrestles with the side effects of successful modernization - with precarious biographies and inscrutable threats that affect everybody and against which nobody can adequately insure" (World at Risk 8). For Beck, these risks can only be understood and managed through science. In his book titled Risk and Society: Towards a New Modernity, Beck notes that we live in a world where "science becomes indispensable, and at the same time devoid of its original validity claims" (Risk 165). He uses unemployment to illustrate the deteriorating living conditions in European modern societies in the wake of science and technology. He specifically points to

an ongoing process in the job market, where unskilled or low-qualified jobs are outsourced or replaced by machines, so that the low-income groups in society do not have any opportunities for getting a job. Thus, they do not experience integration into society and identity building through work anymore, and they fall into a category of people that are left over and irrelevant. They form a group of people where the old differentiation between work and capital, rooted in industrialized modernity and its class society, does not have the same meaning anymore (Wimmer and Quandt 338).

Beck calls this new state of affairs "reflexive modernization" or the unintended unforeseen side-effects of modern life on modernity itself which has affected the way human beings live and perceive reality. Beck is of the view that human beings "do not experience a linear modernization, but a reflexive one, where a successful working society already carries the seeds of its own dissolution, of its own change through unwanted side-effects" (Wimmer and Quandt 338). He further states that "this reading of the events is not limited to France or Europe, but it can be applied to other parts of the post-industrialized world as well" (338). Beck, of course, is not alone in his observations. Anthony Giddens also recognizes this strange paradox in late European modern society, noting that risk might in fact be increasing due to technology, science and industrialism rather than be abated by scientific and technological progress.

Beck and Giddens' views of the risk society appear to suggest that there is a close affinity between people at the receiving end of the social consequences of reflexive modernity on the one hand and, on the other, migrants, since both groups suffer from marginalization and/or exclusion due to class, gender, race and other bases of social inequality. In the assessment of Aaron Doyle, the marginalized "are often seen as being both at risk and risky themselves" (Doyle 8). Doyle's construction of this category of people is that they "are exposed to more risks, but are also themselves categorized as bad risks: this constitutes part of the process of their exclusion. Thus, they are people who are [...] seen as a threat" (8). Ironically, people who face social identification and marginalization have a high likelihood of joining terrorism. According to Andrew Silke, there will always be those within the marginalized communities "who will be receptive to radical ideologies advocating changing or reforming the established, mainstream social system" ("Becoming a Terrorist" 39). In my focus on Somali migrants in Norway therefore, I demonstrate how the novel's central characters are either implicitly or explicitly construed to be a threat to social peace and, consequently, they are kept under surveillance by their host country. ${ }^{1}$

Implicit in Beck's conception of risk society is a second key concept, namely trauma. In other words, the assumption behind anticipating danger is that the more unsafe one feels, the more anxious one will be, and vice 
versa. Indeed, it could be said that a society at risk lives in doubt and fear, always wary of the lurking danger. Such a 'way of living' induces trauma and frustration in people. In the context of North of Dawn, these frustrations are both self-willed and the result of Somalia's fractured collective past which pushes its citizens into spaces where they are made constantly to question themselves in the wake of their loss. Much of the novel is spent on how the central characters' fractured pasts are brought to bear on their present lives. This past is the civil war that Mugdi, Gacalo and a host other Somalis living in exile (in the narrative context of the novel) experienced in Somalia, either first hand or by proxy.

One thing that needs reiterating then, is that Somalia is a country violently riven from within, and the community in Farah's North of Dawn is, at best, at risk. The specificities of risk for the characters in the novel revolve around the kinds of social exclusion they face wherever they go, or the way they are defined and differentiated with reference to the violence they escaped back in Somalia. The effect of this violence is that it causes inner damage to individuals. Most experts agree that key to understanding this inner damage is by understanding the traumatic events or experiences that caused it. In psychological terms, trauma is a deeply distressing or disturbing experience, as well as the mental and emotional after-effects of that experience.

It would seem fair to say, then, that fear, anxiety and risk have a way of creating the traumatized subject. This subject can be an individual, a society or even a culture. From this perspective, the catastrophes that have happened in Somalia must be seen as creating different symptoms of posttraumatic stress disorders (PTSD) in the postcolonial Somali community both at home and outside it. In the Diagnostic and Statistical Manual of Mental Disorders, the American Psychiatric Association's construction of PTSD is that it is a potentially serious debilitating condition that usually occurs in people who have experienced or witnessed a natural disaster, an accident, war, or any other infraction in their lives. Such people often have flashbacks, sadness, anxiety, depression, guilt, anger, grief, fatigue, pain, confusion, despair, loss of self-esteem, loss of trust, nightmares or recurrent and intrusive memories of the traumatizing event.

For such people, a disturbed personality follows them, and its relationship to the violence that informs their lives is undeniable. In the narrative context of North of Dawn, what makes trauma so difficult to forget is that the social and political context that forms the backdrop to the novel is riven with violence and, to date, the body politic is yet to recover from the pestilence that followed in the wake of the carnage in 1991. Farah engages with the postcolonial predicament of the Somali nation when the narrator of North of Dawn notes that "the disintegration of Somalia remains a live issue, very much still unfolding. Nothing quite like it has happened elsewhere before, in Africa or anywhere else - an entire country collapsing in on itself like a tower of cards" (294).

Overall, understanding risk society in relation to living in fear lends itself to a precariatized view. Here, the precariat is, or becomes, a danger both to him —or herself and his or her society because, as Standing also observes, the precariat are habituated to a life of uncertainty, instability and insecurity. More crucially, they are "floating, rudderless and potentially angry, capable of veering to the extreme right or extreme left politically and backing populist demagoguery that plays on their fears or phobias" (Precariat 4). They are also very much capable of venting their frustrations on others. Psychologists use the word projection to refer to the kind of behavior demonstrated by people such as the precariat. The thinking around the term is that people who find certain thoughts, beliefs, and ideas unacceptable, get rid of these by placing them onto others. If someone believes that he or she is worthless, the person is likely to place this feeling of self-worthlessness onto others. Part of what is so interesting and troubling about projection is that once the hated characteristics, thoughts, and feelings that are unacceptable to one's self are placed in the outside world, they take on a life of their own. As I discuss in the next section, Waliya and her fellow fundamentalists act the same way. They resort to committing violence against foreigners because they feel frustrated and neglected. Farah's text thus seems to suggest that there is a post-1991 fragmentation in the psyche of most Somalis; one that, according to Judith Herman, "tears apart a [person's] complex system of self-protection that normally functions in an integrated fashion" (34) and leaves him or her lead a haunted life.

\section{Walking the path of radicalism in North of Dawn}

In Eastern Africa, violent Islamist extremism seems to have found a fertile ground to flourish because of the interpenetrating contours of war and violence due to the region's fluid, unresolved and contested borders. ${ }^{2} \mathrm{Al}$-Shabaab mentioned in North of Dawn is just one of the terrorist groups that have found a good niche in the region, with most its activities concentrated in Somalia. The group in question is opposed to the Somali government and carries out attacks in and around Mogadishu. ${ }^{3}$ The fact that Farah makes reference to the group-through Dhaqaneh's 
involvement in a bomb attack outside Mogadishu -is a clear indication that he is aware of the threat such groups pose to society. For Farah, this awareness is real considering that he lost his sister Basra Farah Hassan to a terror attack in 2014 when a Sunni Islamic fundamentalist organization called the Taliban bombed a restaurant in Kabul where she was working for UNICEF. Spatially then, the narrative texture of North of Dawn brings out elements of radicalism through the pestilence that prevailed in Somalia since Barre was ousted from power, which replicates itself in the novel's characters in their invocation of distorted interpretations of Islam to engage in violent extremism. Peter Hitchcock opines that reading Farah's fiction, "one can correlate these excesses of characterization with the ambiguities of national identity itself" (90). In his writing, Farah seems to relate with observations made in the UN Secretary General's report on Plan of Action to Prevent Violent Extremism, that, "Nothing can justify violent extremism, but we must also acknowledge that it does not arise in a vacuum. Narratives of grievance, actual or perceived injustice, promised empowerment and sweeping change become attractive where human rights are being violated, good governance is being ignored, and aspirations are being crushed" (United Nations, "Plan of Action to Prevent Violent Extremism" 2-3).

Commensurate with the observations made above, Farah engages with the postcolonial predicament of the Somali nation to argue that violence in Somalia has taken on a monstrous aspect that continues to produce a ripple effect on its citizenry both at home and abroad. What seems to baffle Farah (and the world at large) is that Somalia is arguably the most homogenous society on the African continent: "The world could not decipher the signposts. A people with the same singular culture, the same religion, and the same language tearing into one another for reasons that make no sense to those outside the peninsula: that is why. As the saying goes, a stream cannot rise above its own source" (North 295). This does not mean that cultural homogeneity cannot be given to filial conflict. There is dynamism in cultural homogeneity. Therefore, revolution is bound to happen. However, one wishes that conflict and lack of governability that are synonymous with the postcolonial Somali state were resolved within this dynamism. In all, Farah sees a nation whose citizens are left to wander through the debris of fratricidal violence running the risk of causing more harm unto themselves and those around them.

Somalia, having once been termed "a country in exile" by Farah ("A Country in Exile") could be said to have produced what Standing has elsewhere called nostalgics, which, in his view, is a curious faction of the precariat that largely consists of "migrants and beleaguered minorities, who feel deprived of a present time, a home, a belonging" ("Meet the Precariat" n. p.). Standing is of the view that once the precariat recognize their supplicant status, "they mostly keep their heads down politically. But occasionally the pressures become too great and they explode in days of rage" ("Meet the Precariat" n. p.). One major issue that Farah deals with in his novel then, is that of the irrepressible rage some of his character express through violent Islamist extremism. ${ }^{4}$ This concept of violent Islamist extremism, in which Reid Hutchins contends, martyrdom and suicide terrorism are erroneously perceived as "a basic yet lethally effective strategy among radical jihadists to inflict maximum casualties and damage to increase the shock value" (Hutchins 7) can be connected to the character and actions of Dhaqaneh and Waliya in North of Dawn in several way, as I discuss later in this article.

North of Dawn foregrounds Eurocentric perceptions of Africa (Herodotus, Joseph Conrad, Joyce Cary, etc.) dotting the text, which seem to suggest that Africa is not only different, but also threatening, uncouth, full of savagery, bestial and dangerous. The novel's special claim is that the actions of the radical Muslim groups get greater condemnation if the perpetrators are Muslim and black. As Kaluun, one of the characters in the novel observes, "[w]hen you are Muslim and black, in the way Somalis are, you belong at one and the same time to the two minority groups most hated nearly everywhere" (North 224). The condemnation is almost lukewarm and less visceral where a European citizen is involved in acts of terror. According to Kaluun, "[W] hen a native European is responsible for such a rampage, every attempt is made to prove that he was suffering from some form of mental disorder or is emotionally impaired" (North 222). This is further exemplified in the novel through the character and actions of Anders Behring Breivik, a Norwegian far-right terrorist behind the 2011 Norway attacks in which seventy-seven people lost their lives. Breivik "detonated a bomb close to the Norwegian premier's office in the center of Oslo, in which eight people lost their lives" (209). Thereafter, he headed himself "to the wooded island of Utøya, where the young acolytes of the country's governing Labor Party were attending youth camp, and proceeded to mow down sixty-nine more, most of them teenagers" (209). Kaluun wonders that if Breivik is described by his compatriots as mad, "the radical Muslim groups should be described as mad too rather than "haters of the West' or some such" (222). The point Farah appears to emphasize through the character of Kaluun here is that the demonization of Islamist extremism will always be ill-suited if it is limited to foreign radical Muslim groups as 
perpetrators of evil, leaving out right-wing native purists like Breivik. What is most troubling is that stereotypes about all terrorists being Muslims have tended to resonate in most Western societies.

These observations notwithstanding, a more nuanced analysis of radicalism in North of Dawn has to focus on Dhaqaneh and Waliya's association with radical jihadism (and how Mugdi, Gacalo and other naturalized Somalis must comport themselves among their western friends and acquaintances); because this is the nerve center around which the lines feeding the conflicts, tensions and mapping out of identities converge.

Given the current reality of terrorism as defining of the zeitgeist of the twenty-first century (Boehmer and Morton 8), themes of precarity and extremism are gaining traction in African writing. Yet, as Islamist extremism becomes the new norm, its attendant woes—risk, terror and trauma - seem to be on the rise as well. The implication here is that the possible comforts of being in a risk-free environment are being challenged by changes in both postcolonial state formations and the way citizens react to the social ills prevalent around them, thereby making peaceful living a complex process that challenges human life. In a helpful review of terrorists, Silke notes that they "are essentially normal individuals" ("Cheshire-cat logic: The recurring theme of terrorist abnormality in psychological research" 53). His observations are strengthened by research done by Nasr Hassan who also asserts that " $[\mathrm{w}]$ hat is frightening is not the abnormality of those who carry out the suicide attacks, but their sheer normality. They are so normal for their communities and societies" (n. p.). These views point to an increasingly prevalent tendency in explaining the psychology of terrorists: they are normal people who are not driven by some psychological disorder. In actual fact, most of the suicide terrorists have emerged from secular backgrounds; their profiles do not fit that of the suicidal individual we later come to know (Zulaika 98).

In North of Dawn, Dhaqaneh seems to reflect this terrorist normality since nothing untoward is said about his childhood or the reasons why he took the path of radicalism. We learn that as a child, "he never said his prayers" and "he wasn't in the least religious [...] until much later, as a grown man, just before he joined the Shabaab" (North 131). More crucially, he is portrayed as a man of peaceful disposition who always "thought of himself as a bridge-builder, a bringer-together of peoples from different beginnings, a Somali proud of his place in Europe" (180). His sanguine nature is further shown by the fact that, as a young man, he used to be very upset with anyone who "was so uncaring and emotionless that he could bring himself to kill an Arab" (180). Although these words are spoken out of youthful exuberance, they carry a kernel of truth, and using the Arab world Dhaqaneh could be said to be against acts of terror so often wrongly associated with people belonging to his religion, preferring a peaceful coexistence instead. This element of calmness and tolerance wears off with age. He gets radicalized after joining a terrorist cell in Oslo and, later, develops a strong aversion for Christianity which he considers a religion for infidels, to the extent that "he cannot bring himself to carry a [Norwegian] passport whose cover is adorned by a cross, such a flagrant Christian symbol" (2). He instead chooses to keep a Somali passport and remain in Somalia because the country "was the closest [Somalis had] to an Islamic state, after Iran" (3). Dhaqaneh is probably alluding to Somalia's close affinity to the Islamic State of Iraq and Syria (ISIS), a Sunni Islamic organization known for using violent ideology to construct and consolidate Jihadism over the Muslim world.

The sense of becoming a suicidal terrorist gains traction in the novel when Dhaqaneh, in what Melanie Finn suggests to be a proxy war "for the global clash between fundamentalism and secularism" (n. p.), stands up to his father and tells him that he, Dhaqaneh, would not hesitate to exterminate non-Muslims because he views them "as creatures bereft of souls" and, therefore, "he wouldn't hesitate to exterminate [non-Muslims]" (North 20). Dhaqaneh declares that "Islam was the one faith that would save the world and everyone on it from perdition and, if need be, he was prepared to kill to achieve this" (18). He further starts using these threats after he gets indoctrinated by a religious mentor who was "suspected of links to one of the 9/11 bombers" (19). Painted here is a picture of violent Islamist extremism which construes all "non-Muslims and 'wrong' Muslims [...] as eternal enemies of 'true' Islam and therefore fit to be exterminated" (Wilkinson 53). Thus, it comes as no surprise when we later learn about the explosions in Mogadiscio becoming "more frequent and deadly, with fingers of blame pointing at him" (North 3). The point to be made here then, is that Dhaqaneh embraces a religious rhetoric of Islamist extremist groups that conflates the Islamic concepts of sacrifice, martyrdom and Jihad to propagate a narrative of violent self-sacrifice, redemption and divine reward for its followers.

Many scholars regard sacrifice, martyrdom and Jihad as "Islamic concepts that have been distorted and exploited by [terrorist organizations] to pursue an extreme Pan-Islamic vision" (Hutchins 7; Haleem 164). According to Hutchins, these Islamist movements have deliberately "misconstrued and exploited the intended usages and true meanings of these Islamic concepts for recruitment purposes. Their erroneous claims and propaganda 
have misled their followers into believing that suicide terrorism is morally permitted and justified" (Hutchins 7; see also Haleem 164). In the narrative context of North of Dawn, these erroneous claims trouble the strict designations of Islam as a peaceful religion, creating Islamophobia instead. They also invite us to read the novel as writing terrorist subjectivities; one that "offers a counter-narrative to the clash-of-civilizations explanation of Islamist extremism" out of its insistence that "there is nothing distinctly Islamic about Islamist extremism, much less to excuse its violence and brutality" (Haleem 164; original emphasis). This is exemplified in the text through the character of Mugdi who is disgusted and affronted by his son's involvement in terrorist activities. Mugdi asks, "how can I mourn a son who caused the death of so many innocent people? It makes no sense to grieve his death. I explode into rage every time I remember what he did" (North 91). Unlike Gacalo, who has a soft spot for her son, Mugdi does not grant operations that in effect sanction the killing and maiming others for religious or political gain. Besides, he knows that associating himself with his son's warped beliefs and what they represent will not put his name in good stead among his white Norwegian friends.

Waliya, Dhaqaneh's wife, is the character over whom we watch Gacalo and Mugdi literally fight and almost ruin their marriage in the novel. Like Dhaqaneh, she not a fundamentalist by birth. She gets radicalized by her husband after a long period of ambivalence and living a life of prostitution in a refugee camp in Kenya. When Waliya arrives in Norway, she makes a good contrast between Europe and Africa.

She also praises Gacalo's generosity, saying: "[T]his is the first time that each of us has a proper bedroom, with beds much larger than any we've ever slept it. This is also the first time when we've lived without frequent power outages and when we could pray without fear" (101). She again thanks Gacalo for providing her and her children "with so many of these comforts" (101). Unfortunately for Gacalo, Waliya drastically revises the terms of the older woman's hospitality towards her. She disavows and rejects her parents-in-laws out of her belief that they are not Muslim enough. In her view, her parents-in-law belong to the 'wrong' or deficient Muslim group; one that "is not politically engaged in the establishment of the Islamic State" due to its association and collaboration with the non-Muslims (Wilkinson 70). She thus begins to regard them as "apostates" (263) or "the 'impure,' 'damned' camp of the infidel" (Wilkinson 71) who, through their association with the non-Muslims, have failed to maintain the purity in Islam. Needless to say, Waliya takes a "perverse resolve to cut off all ties to Gacalo and the rest of the family" (North 263) and aligns herself with "the 'true' Muslim 'in-group' [...] committed to establish an Islamic State" or its equivalent into existence (Wilkinson 78). In calling them apostates, they are easily "turned [...] into vulnerable clay pigeons, fair targets that Jihadi terrorists could take potshots at" (North 263).

Waliya's reversion happens soon after she finds herself "among her people" in Norway by which the narrator means that she has reconnected with Imam Zubair, described in the novel as Dhaqaneh's "comrade in arms" (363). Soon afterwards, Zubair - a man wanted by the Norwegian antiterrorist unit for engaging in terrorist activities - and Imam Fanax begin to support "her refusal to accept social welfare benefits from a non-Muslim entity such as the Norwegian state" (124). As expected, Waliya's apartment complex in Norway is soon turned into a rendezvous for the two extremist imams and her neighbors lodge a complaint with the authorities for "disturbing the entire neighborhood through a recitation of the Koran via a loud sound system" (North 89). Slowly, but consistently, she begins to disapprove of her son's association with Christians who make him eat "their haram food" (101). For Waliya, the West is full of "nativist skinheads so violently opposed to foreigners in their midst" (148). Needless to wonder, Charles describes the novel as "bracingly honest about the difficulties of assimilation, the way hospitality curdles into condescension and gratitude sours into resentment" ("North of Dawn" n. p.) for the radicalized Somali migrant.

In realigning and reconnecting with Imams Zubair and Fanax in Norway, Waliya seeks to perpetuate the "good work" she and her husband started back in Somalia Unfortunately for the trio, they are rounded up by Norwegian antiterrorist authorities, who put the two imams behind bars, while Waliya is repatriated to Somalia. The impression the reader is left with about Waliya even in the closing pages of the book is that her new job as "a concierge in Mogadiscio" (North 365) is only as a conduit for more acts of terror. In this instance, at least, the idea exists of Somalia as "a country that's at war with itself" (365) which, in turn, creates collateral violence on those that lie directly in its path is of some value.

It is interesting to consider the extent to which Waliya's and Dhaqaneh's actions impact on their immediate family members and the other Somalis living in Norway. For Mugdi, the perception he has of his daughter-in-law does not change throughout the novel since, as I have previously mentioned, she reminds him of the past. This reminder becomes more poignant in the novel when Waliya is associated with the deaths of both Dhaqaneh 
and Gacalo in the narrative context of the book. ${ }^{5}$ Mugdi further thinks that "by associating with Waliya and, by extension, Zubair, Imam Fanax, and Arla, [he] has crossed a line that now makes him of interest to the police" (355). The point that Farah makes through the character of Mugdi here is that Waliya's actions have a ripple effect on those she comes in contact with. Gacalo is left in a state of shock when she learns of the younger woman's fraternization with the two imams. She feels "like a purchaser of contraband goods from an illegal outlet bought at bargain prices, with no warranty period to return them, if they turn out to be unsuitable" (249). In taking the word "contraband" as a foundation for his reflections about Waliya's character in Norway, Farah appears to bring up aspects of illegality and secrecy which are often associated with migrant lives to account for the precarious substance of such lives.

If precariousness, or some variant of it, can be regarded as creating fear and risk in people, then it could be said that Farah's latest novel inflects the form of anxiety that leaves every Somali wondering what the future holds for them. Thus, North of Dawn warns of the dangers of radical jihadism as a 'way out' in a fatally fragmented Somali postcolony. Over a quarter of a century after Barre was deposed from power, Somalis are still haunted by its legacy. As Terrence Lyons and Ahmed Samatar assert in Somalia: State Collapse, Multilateral Intervention, and Strategies for Political Reconstruction, after the collapse of power in 1991 "the Somali people suffered the horrible brutality of living in a Hobbesian world without law or institution to regulate relations among groups or to protect the most vulnerable from the most vicious" (7). In the context of this article, violent Islamist extremism places the novel's characters' atypical identities in a state of precarity that requires reframing the postcolonial/raced Somali émigré.

\section{Conclusion}

In conclusion, precarity and extremism play an important part in the construction of the dislocated Somali subject in Nuruddin Farah's North of Dawn. The precariat condition of the characters in the novel induce feelings of rage, which push some of them into acts of terror. I have shown in this article how the author's decision to write terrorist subjectivities endorses the assertion that Somalia's internecine conflicts have over time produced a curious faction of the precariat, some of which have become a danger both to themselves and their immediate neighbors. The novel thus highlights the manner in which dislocation, marginalization and social identification have the power of turning the quiet subject into an explosive character.

\section{Notes}

1 A disclaimer is needed here: speaking of a Somali migrant community in terms of being associated with extremism is by no means painting all Somali émigrés with one brush.

2. I use the term Eastern Africa in this study to refer to the vast region extending from Sudan in the north to Tanzania in the south. The study understands the region as comprising of Burundi, Comoros, Djibouti, Eritrea, Ethiopia, Madagascar, Mauritius, Rwanda, Seychelles, Somalia, South Sudan, Sudan, Kenya, Tanzania and Uganda. Of course, this demarcation has its own downside, with Tom Odhiambo and Godwin Siundu observing in their editorial to the inaugural issue of Eastern African Literary and Cultural Studies journal that countries such as "Eritrea, Djibouti; or even the eastern parts of the Democratic Republic of Congo, the Comoros or Seychelles" fall outside "the common understanding of [what is called] eastern Africa" (1). In this study, then, "Eastern Africa" is not a settled term.

3. I am constrained by space and the focus of this paper from examining the reasons behind al-Shabaab attacks in Somalia and its reach across other parts of Eastern Africa, or the reasons why Dhaqaneh and Waliya join the group in the narrative context of North of Dawn.

4. According to Matthew Wilkinson, violent Islamic extremism is "the extreme Manichean Islamist ideology by which the cosmos is constructed as a manifestation of the Eternal Struggle between Islam and Unbelief (Kufr)" (Wilkinson 53).

5. Back in Mogadiscio, before she fled to Norway, Waliya was the one who was tasked with the task of detonating the bomb that took so many innocent lives. She was reluctant to take up this mission and Dhaqaneh, her husband, took up the assignment instead. Later in the novel, Gacalo dies of grief and shock upon learning about her daughter-in-law's involvement with extremist elements.

\section{Works Cited}

Alden, Patricia \& Louis Tremaine. Nuruddin Farah. Twayne, 1999.

Arendt, Hannah. Eichmann in Jerusalem: A Report on the Banality of Evil. Viking, 1963.

American Psychiatric Association. Diagnostic and Statistical Manual of Mental Disorders. 5th Edition: DSM-5. American Psychiatric, 2013.

Beck, Ulrich. Risk Society: Towards a New Modernity. Sage, 1992. World at Risk. Polity, 2007.

Boehmer, Elleke \& Stephen Morton. "Introduction: Terror and the Postcolonial." Terror and the Postcolonial, edited by Elleke Boehmer \& Stephen Morton. Blackwell, 2010, pp. 1-24.

Bourdieu, Pierre et al. The Weight of the World: Social Suffering in Contemporary Society. Stanford U P, 1999. 
Charles, Ron. "North of Dawn by Nuruddin Farah, Review: The Somali Novelist Channels the Pain of his Sister's Death in a Terror Attack." Independent. 21 Dec. 2018. www.independent.co.uk/arts-entertainment/books/reviews/north-of-dawnnuruddin-farah-book-review-terrorism-sister-novel-a8694206.html. Accessed 24 Dec. 2019.

Doyle, Aaron. "Introduction: Trust, Citizenship and Exclusion in the Risk Society." Risk and Trust: Including and Excluding the Citizen? edited by Law Commission of Canada. Fernwood, 2009, pp. 7-22.

Farah, Nuruddin. “A Countryin Exile.”WorldLiterature Today vol.72,no. 4,1998,pp. 713-15.DOI: https://doi.org/10.2307/40154257. . North of Dawn. Riverhead, 2018.

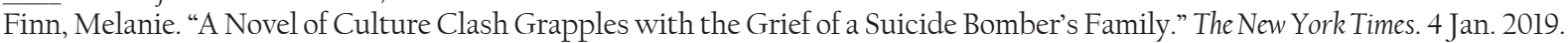
ww.nytimes.com/2019/01/04/books/review/north-of-dawn-nuruddin-farah.html. Accessed 26 Dec. 2019.

Haleem, Irm. The Essence of Islamist Extremism: Recognition through Violence, Freedom through Death. Routledge, 2012.

Han, Clara. "Precarity, Precariousness, and Vulnerability." Annual Review of Anthropology vol. 47, 2018, pp. 331-43. DOI: https:// doi.org/10.1146/annurev-anthro-102116-041644.

Hassan, Nasr. "An Arsenal of Believers: Talking to the "Human Bombs." Paper presented at the International Society of Political Psychology Conference, 16-19 July, Berlin, Germany, 2002.

Herman, Judith Lewis. Trauma and Recovery: The Aftermath of Violence —From Domestic Abuse to Political Terror. Basic, 1992.

Hitchcock, Peter. The Long Space: Transnationalism and Postcolonial Form. Stanford U P, 2010.

Hutchins, Reid. "Islam and Suicide Terrorism: Separating Fact from Fiction." Counter Terrorist Trends and Analyses vol. 9, no. 11, 2017, pp. 7-11.

Lyons. Terrence \& Ahmed I. Samatar. Somalia: State Collapse, Multilateral Intervention, and Strategies for Political Reconstruction. The Brookins Institution, 1995.

Menkhaus, Ken. "Governance without Government in Somalia Spoilers, State Building, and the Politics of Coping." International Security vol. 31, no. 3, 2007, pp. 74-106. DOI: https://doi.org/10.1162/isec.2007.31.3.74.

Mohamed, Hassan A. "Refugee Exodus from Somalia: Revisiting the Causes." Refugee: Canada's Journal on Refugees vol. 14, no. 1, 1994, pp. 6-10

Odhiambo, Tom \& Godwin Siundu. "Journeying into Eastern African Literary and Cultural Studies." Eastern African Literary and Cultural Studies vol. 1, nos. 1-2, 2014, pp. 1-6. DOI: https://doi.org/10.1080/23277408.2014.982350.

Ridout, Nicholas \& Rebecca Schneider. "Precarity and Performance: An Introduction." Arcade: Literature, the Humanities, and the World. arcade.stanford.edu/content/precarity-and-performance-introduction. Accessed 24 Dec. 2019.

Said, Edward W. "The Essential Terrorist." Blaming the Victims: Spurious Scholarship and the Palestinian Question, edited by Edward W. Said \& Christopher Hitchens. Verso, 1988, pp. 149-58.

Schwartz, Allan. "Hatred, Terrorism and Trauma." Mentalhelp.net. 27 Nov. 2006. www.mentalhelp.net/articles/hatred-terrorismand-trauma/. Accessed 24 Dec. 2019.

Silke, Andrew. "Becoming a Terrorist." Terrorists, Victims and Society: Psychological Perspectives on Terrorism and its Consequences, edited by Andrew Silke. Wiley, 2003, pp. 29-54.

. "Cheshire-cat logic: The recurring theme of terrorist abnormality in psychological research." Psychology, Crime and Law vol. 4, 1998, pp. 51-69. DOI: https://doi.org/10.1080/10683169808401747.

Standing, Guy. The Precariat: The New Dangerous Class. Bloomsbury Academic, 2011.

"Meet the Precariat. The New Global Class Fueling the Rise of Populism." World Economic Forum. 9 Nov. 2016. www. weforum.org/agenda/2016/11/precariat-global-class-rise-of-populism/. Accessed 24 Dec. 2019.

United Nations. "Plan of Action to Prevent Violent Extremism." Seventieth Session. Dec. 2015. www.un.org/en/ga/search/ view doc.asp?symbol=A/70/674. Accessed 24 Dec. 2019.

Wilkinson, Matthew L. N. The Genealogy of Terror: How to distinguish between Islam, Islamism and Islamist Extremism. Routledge, 2019.

Wimmer, Jeffrey \& Thorsten Quandt. "Living in the Risk Society: An interview with Ulrich Beck." Journalism Studies vol. 7, no. 2, 2006, pp. 336-47. DOI: https://doi.org/10.1080/14616700600645461.

Zulaika, Joseba. Terrorism: The Self-Fulfilling Prophecy. U of Chicago P, 2009. 